\title{
NEW YORK GROUND-WATER QUALITY
}

\author{
By R.J. Rogers, U.S. Geological Survey \\ and \\ Staff of Division of Water, New York State \\ Department of Environmental Conservation
}

U.S. Geological Survey Open-File Report 87-0742 


\section{DEPARTMENT OF THE INTERIOR \\ DONALD PAUL HODEL, Secretary}

\section{U.S. GEOLOGICAL SURVEY}

Dallas L. Peck, Director

For additional information:

Chief Hydrologist

U.S. Geological Survey

407 National Center

Reston, VA 22092
For sale by:

U.S. Geological Survey

Books and Open-File Reports Section Federal Center

Box 25425

Denver, Colorado 80225

Use of trade names in this report is for descriptive purposes only and does not constitute endorsement by the U.S. Geological Survey 


\section{FOREWORD}

This report contains summary information on ground-water quality in one of the $\mathbf{5 0}$ States, Puerto Rico, the Virgin Islands, or the Trust Territories of the Pacific Islands, Saipan, Guam, and American Samoa. The material is extracted from the manuscript of the 1986 National Water Summary, and with the exception of the illustrations, which will be reproduced in multi-color in the 1986 National Water Summary, the format and content of this report is identical to the State ground-water-quality descriptions to be published in the 1986 National Water Summary. Release of this information before formal publication in the 1986 National Water Summary permits the earliest access by the public. 
Contents

Ground-Water Quality $\ldots \ldots \ldots \ldots \ldots \ldots \ldots \ldots \ldots \ldots \ldots \ldots \ldots \ldots \ldots \ldots \ldots$

Water-Quality in Principal Aquifers $\ldots \ldots \ldots \ldots \ldots \ldots \ldots \ldots \ldots \ldots \ldots \ldots \ldots \ldots \ldots$

Background Water Quality $\ldots \ldots \ldots \ldots \ldots \ldots \ldots \ldots \ldots \ldots \ldots \ldots$

Effects of Land Use on Water Quality $\ldots \ldots \ldots \ldots \ldots \ldots \ldots \ldots \ldots \ldots$

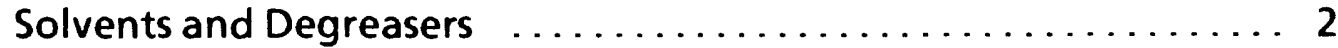

Gasoline and Petroleum Products $\ldots \ldots \ldots \ldots \ldots \ldots \ldots \ldots \ldots \ldots$

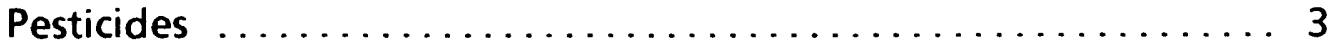

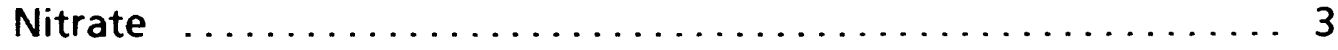

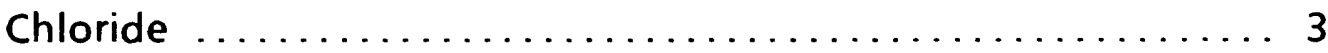

Other Organic Chemicals and Toxic Metals .............. 3

Potential for Water-Quality Changes $\ldots \ldots \ldots \ldots \ldots \ldots \ldots \ldots \ldots \ldots$

Ground-Water-Quality Management $\ldots \ldots \ldots \ldots \ldots \ldots \ldots \ldots \ldots \ldots, 4$

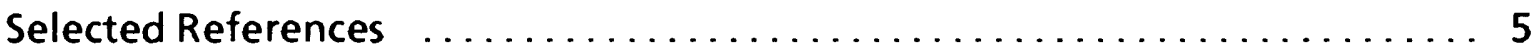

Illustrations

Figure 1.--Selected geographic feature and 1985 population distribution in New York.

Figure 2.--Principal aquifers and related water-quality data in New York. . . . 7

Figure 3.--Selected waste sites and ground-water quality information in New York. ................................. 8

Figure 4.--Dissolved-solids and nitrate in the upper glacial and Magothy aquifers of Nassau and Suffolk Counties, Long Island, 1960-84. . . 10 


\section{NeW York Ground-Water Quality}

Ground water is the source of supply for approximately 6.2 million of New York State's 17.5 million residents. More than onehalf of those relying on ground water live on Long Island, one of the most densely populated areas of the State (fig. 1). The chemical quality of water in the State's major aquifers is generally good for most uses and does not exceed the drinking-water-quality standards established by the New York State Department of Health (NYSDOH). Naturally large concentrations of dissolved solids, iron, and manganese restrict use in some localized areas. In some parts of the State, primarily on Long Island, concentrations of nitrate, as nitrogen, exceed the State recommended drinking-water standard of $10 \mathrm{mg} / \mathrm{L}$ (milligrams per liter). These exceed naturally occurring concentrations and are attributed primarily to urbanization and, to a lesser extent, agriculture.

The New York State Department of Environmental Conservation (NYSDEC) has identified contamination by synthetic organic chemicals (sOC) as the most serious ground-water-quality problem in the State. Since 1978, soc in ground water have caused the closing of more than 120 public water-supply wells, about 75 percent of which are on Long Island. Most of the well closings have been due to chemicals used as solvents and degreasers, but some have been due to petroleum products and pesticides. The SOC contaminants are associated mainly with accidental leaks and spills and poor industrial housekeeping, all of which accompany urbanization, but also are derived from domestic sewage systems and agriculture. Other widespread potential sources of soc contaminants are the State's approximately 300 confirmed hazardous-waste-disposal sites and 420 municipal landfills.

Many of New York's most important aquifers lie beneath areas of substantial to intensive urban, industrial, and agricultural development. Development over these aquifers will continue in the future, and although contaminant sources associated with future development will be controlled, the potential for contamination by accidental spills and leaks will remain. Contamination by SOC is expected to remain the State's greatest ground-water-quality problem.

\section{WATER QUALITY IN PRINCIPAL AQUIFERS}

The principal aquifers in New York consist of (1) unconsolidated glacial stratified-drift deposits that are composed chiefly of sand and gravel, (2) unconsolidated coastal-plain aquifers, and (3) sandstone and carbonate bedrock aquifers (U.S. Geological Survey, 1985, p. 323). For convenience of discussion, these aquifers are grouped into two regions-upstate New York and Long Island. Upstate New York, as used here, includes all counties north of New York City (fig. 1). Ground water under New York City, except for parts of the Boroughs of Queens and Brooklyn on western Long Island, is not considered in this summary, as it is a minor source of supply. The geographic distribution of principal aquifers is shown in figure $2 A$. "Principal aquifer", as used in this summary, does not have the same meaning as, and should not be confused with, the term used by the New York State Department of Environmental Conservation $(1987 ; 1987)$ in the State's ground-watermanagement programs.

Upstate New York. -Stratified-drift deposits that underlie flood plains and terraces along larger valleys generally form the most important aquifers. In upstate New York, glacial-lake and beach sand in upland areas also may contain significant aquifers. Bedrock is a significant aquifer only in the sandstone formations of Rockland, St. Lawrence, Franklin, and Clinton Counties and in areas of carbonate rock across the State.

The major use of ground water in upstate New York is for public and domestic drinking-water supplies (U.S. Geological Survey, 1985, p. 323). About 1 million people in upstate New York rely on public water supplies that use ground water, primarily from valley-fill aquifers. Virtually all rural residents of upstate New York, about 2 million people, obtain their drinking water from private domestic wells, some of which have significant yields from stratified-drift deposits and bedrock aquifers, but most from lowyielding aquifers that underlie most of upstate New York.

Long Island. - Long Island is underlain by the largest aquifer system in New York State. The system consists of three aquifers of unconsolidated clastic sediments-the upper glacial, the Magothy, and the Lloyd aquifers (fig. $2 B$ ). These three aquifers are continuous throughout most of Long Island except along the north shore and parts of the western end of the Island where the Magothy and Lloyd aquifers are absent.

Long Island's aquifer system supplies more than 3.2 million people, including the entire population of Nassau and Suffolk Counties and about 500,000 New York City residents in Queens (New York State Department of Environmental Conservation, 1986, p. I-4). About 300,000 Long Island residents, mostly in Suffolk County, rely on private domestic wells; the remainder are served by community systems that withdraw water primarily from the Magothy aquifer.

\section{BACKGROUND WATER QUALITY}

Ground water in most areas of New York is of good quality and suitable for most uses, including human consumption. Locally, however, water in areas of stratified-drift deposits in upstate New York and in the upper glacial and Magothy aquifers of Long Island contains iron and manganese from natural sources that exceed drinking-water standards. Some stratified-drift deposits and shallow bedrock aquifers between Buffalo and Syracuse (fig. 1) yield slightly to moderately saline water as the result of solution of evaporite minerals in the bedrock (U.S. Geological Survey, 1985, p. 324). Some wells in nearshore areas of Long Island, especially in eastern Suffolk County, yield saline water as a consequence of saltwater intrusion caused by excessive pumping (U.S. Geological Survey, 1985 , p. 326).

A graphic summary of selected water-quality variables compiled from the U.S. Geological Survey's National Water Data Storage and Retrieval System (WATSTORE) is presented in figure $2 C$. The range in concentration of four indicators of background water-quality-dissolved solids, hardness (as calcium carbonate), nitrate (as nitrogen), and chloride-in 12 selected aquifers is shown. The data from upstate New York represent (1) the stratified-drift deposits, (2) four important valley-fill aquifers near the cities of Jamestown, Elmira, Endicott, and Schenectady, (3) the carbonate bedrock aquifer, and (4) the sandstone bedrock aquifer (fig. $2 A$ ). The data for the upstate New York aquifers were collected between the late 1940's and early 1980's, although most were gathered between the late 1950's and early 1970's. Data representing the upper glacial and Magothy aquifers of Long Island, collected during 1984-85, are presented separately for Nassau and Suffolk Counties. Data on the Lloyd aquifer represent both Nassau and Suffolk Counties and were collected during 1960-85. Where more than one analysis from a given well was available, the mean concentration was used. 
Percentiles of the selected water-quality variables are compared to national standards that specify the maximum concentration or level of a contaminant in drinking-water supply as established by the U.S. Environmental Protection Agency (1986a,b). The primary maximum contaminant level standards are health related and are legally enforceable. The secondary maximum contaminant level standards apply to esthetic qualities and are recommended guidelines. The primary drinking-water standards include a maximum concentration of $10 \mathrm{mg} / \mathrm{L}$ nitrate (as nitrogen), and the secondary drinking-water standards include maximum concentrations of $500 \mathrm{mg} / \mathrm{L}$ dissolved solids and $250 \mathrm{mg} / \mathrm{L}$ chloride. State standards are the same as the national standards.

All principal aquifers in New York except the carbonate bedrock aquifer have median dissolved-solids concentrations that do not exceed the $500-\mathrm{mg} / \mathrm{L}$ standard for public-water supplies (fig. 2C). The large dissolved-solids concentrations in the carbonate aquifer are due to the solubility of carbonate minerals. Dissolvedsolids concentrations exceeding $1,000 \mathrm{mg} / \mathrm{L}$ in upstate New York aquifers in the western one-half of the State generally can be attributed to areas of naturally saline ground water.

Water in principal upstate New York aquifers generally ranges from hard to very hard. The hardest water occurs in the carbonate bedrock aquifer. On Long Island, ground water is soft. The slightly harder water in Nassau County than in Suffolk County reflects the effects of urbanization.

All principal aquifers in New York have median nitrate concentrations (as nitrogen) that are less than the $10-\mathrm{mg} / \mathrm{L}$ standard for water supplies. The nitrate plot in figure $2 C$ reflects local nitrate contamination, which is widespread in the upper glacial aquifer on Long Island, especially in Nassau County (New York State Department of Environmental Conservation, 1986, p. II-15).

The median chloride concentrations of water in all principal aquifers are appreciably less than the $250-\mathrm{mg} / \mathrm{L}$ standard for drinking-water supplies. The occurrence of saline ground water in some upstate areas and saltwater intrusion in parts of Long Island are responsible for the increased chloride concentrations indicated for some aquifers.

\section{EFFECTS OF LAND USE ON WATER QUALITY}

Although ground-water quality in most of New York is good, quality problems exist in some areas. The problems are considered to be significant, and their extent has not been identified fully in all areas, especially in upstate New York where data are limited (New York State Department of Environmental Conservation, 1987). Many urban areas in upstate New York overlie important valley-fill aquifers; agricultural land also occupies such valleys. On Long Island, all development lies directly above the principal aquifers. Consequently, many of the State's major aquifers are exposed to actual or potential sources of contaminants. Some are nonpoint sources, such as agricultural and urban runoff; others are point sources, such as waste-disposal sites.

The NYSDEC has identified approximately 300 sites that have received hazardous waste or have been contaminated by hazardous material (fig. 3A), and more than 600 additional sites are suspected to have received or been contaminated by hazardous material and are undergoing additional investigation (New York State Department of Environmental Conservation, 1985). The U.S. Environmental Protection Agency (EPA) has included 54 hazardous-waste sites (fig. $3 A$ ) on the National Priorities List (NPL) of hazardous-waste Superfund sites, under the Comprehensive Environmental Response, Compensation, and Liability Act (CERCLA) of 1980. Another 41 waste-disposal sites (fig. $3 A$ ) require monitoring under the Federal Resource Conservation and Recovery Act (RCRA). Approximately 420 municipal solid-waste landfills (fig. $3 C$ ) in the State are active (New York State Department of Environmental Conservation, 1987, p. II-24). Most waste-disposal sites are located outside areas overly- ing the principal aquifers, but more than 100 active municipal landfills lie over or adjacent to important aquifers (New York State Department of Environmental Conservation, 1987, p. II-24). Ground-water contamination has been documented at many wastedisposal sites, and the sites continue to be a significant threat to ground-water quality.

As of September 1985, 42 hazardous-waste sites at 8 facilities in New York had been identified by the U.S. Department of Defense (DOD) as part of their Installation Restoration Program (IRP) as having potential for contamination (U.S. Department of Defense, 1986). The IRP, established in 1976, parallels the EPA Superfund program under CERCLA. EPA presently ranks these sites under a hazard ranking system and may include them in the NPL. Of the 42 sites in the program, 8 sites contained contaminants but did not present a hazard to the environment. Fourteen sites at 3 facilities (fig. $3 A$ ) were considered to present a hazard significant enough to warrant response action in accordance with CERCLA. The remaining sites were scheduled for confirmation studies to determine if remedial action is required.

Contamination by Soc particularly industrial and commerical solvents and degreasers, gasoline and petroleum products, and pesticides, is the greatest threat to the State's ground-water resources (New York State Department of Environmental Conservation, 1987; 1986). Inorganic chemicals also contaminate ground water, but only nitrate, chloride, and metals are of statewide concern. The source and extent of each of these contaminants are discussed below.

\section{Solvents and Degreasers}

Solvents and degreasers contain a variety of toxic organic compounds. The most common ones detected in public-supply wells are the halogenated compounds trichloroethylene, tetrachloroethylene, and 1,1,1-trichloroethane. The State drinkingwater standard for these organic solvents is $50 \mu \mathrm{g} / \mathrm{L}$ (micrograms per liter). The threat to ground water by solvents and degreasers increases with development and population density, as has been documented on Long Island by Eckhardt and others (1987). The most significant sources of these contaminants include: (1) leaks and spills at storage, industrial, and commercial facilities; (2) improper industrial disposal; (3) improper consumer-product use and disposal; (4) landfills; and (5) septic tanks. New York contains many active and inactive hazardous-waste sites and landfills (fig. $3 A, C$ ) that may be sources of solvents, degreasers, and other contaminants. The activities that most commonly release solvents and degreasers to ground water, however, are leaks and spills, poor industrial housekeeping, and domestic use and disposal.

The three aforementioned compounds-trichloroethylene, tetrachloroethylene, and 1,1,1-trichloroethane-alone had caused the closing of about 95 public-supply wells in the State by June 1986 (Ronald A. Entringer, New York State Department of Health, written commun., 1986). Most of these closings were on Long Island (fig. 3B), where general areas of ground-water contamination by organic chemicals have been delineated by the New York State Department of Environmental Conservation (1986, p. II-7). In Suffolk County, Long Island, more than $\mathbf{4 4 0}$ water samples from private wells, or 3 percent of those tested, contained 1,1,1-trichloroethane in concentrations exceeding the State guideline for drinking water (Suffolk County Department of Health Service, 1984).

\section{Gasoline and Petroleum Products}

Potential sources of gasoline and other contaminants derived from petroleum products are numerous and widespread. Leaking underground storage tanks, especially at gasoline service stations, are primary sources of petroleum-product contamination. Petroleum contamination also occurs through accidental spills and mishandling at the land surface. 
The New York State Department of Environmental Conservation (1987, p. II-23) has estimated that New York State has approximately 100,000 underground petroleum-storage tanks with more than 1,100-gallon capacity and that approximately 25 percent of these are leaking. From 1978 to 1983 , approximately 2,300 spills and leaks of gasoline and petroleum products were reported in upstate New York; almost 500 of these affected wells or otherwise violated ground-water standards (New York State Department of Environmental Conservation, 1987, p. II-23). Records of the New York State Department of Transportation show that from April 1978 to March 1980 more than 700 petroleum spills occurred in Nassau and Suffolk Counties, Long Island (New York State Department of Environmental Conservation, 1986, p. II-10).

State ground-water or water-supply standards do not exist for gasoline or other petroleum products. However, guidelines require water supplies to be free of oil and grease and tastes and odors associated with petroleum products. Standards exist, however, for three compounds found in petroleum products-benzene, xylene, and toluene.

Contamination by gasoline or other petroleum products has caused less public water-supply well closings than organic solvents, but more than one-half of the reported contamination problems with individual household wells in the State are related to petroleum products (New York State Department of Environmental Conservation, 1987 , p. II-12). Many violations of ground-water-quality standards by petroleum products that have not affected drinking-water wells also have been reported.

\section{Pesticides}

Contamination of New York State's ground water by pesticides has become a serious concern during the past 10 years. The greatest cause of such contamination is agricultural usage, especially potato farming, but use and disposal of pesticides by homeowners also can create localized problems.

In the potato-farming areas of eastern Suffolk County, Long Island, pesticide contamination has adversely affected both public and private water supplies (fig. $3 B$ ). Aldicarb is the pesticide most widely detected in ground water; others detected include carbofuran, Dacthal, 1,2-dichloropropane, and paraquat. By June 1986, four public-supply wells had been closed in Suffolk County because of pesticide contamination (Ronald A. Entringer, New York State Department of Health, written commun., 1986). The Suffolk County Department of Health Services (1984) is conducting an extensive ground-water monitoring program for aldicarb and other pesticides. By April 1984, aldicarb had been detected in approximately 2,000 private wells in concentrations exceeding the State drinking-water standard for aldicarb of $7 \mu \mathrm{g} / \mathrm{L}$. Aldicarb is no longer in use on Long Island.

Ground-water contamination by pesticides is expected to be less severe and less widespread in upstate New York than on Long Island (New York State Department of Environmental Conservation, 1987, p. II-30), although the extent of ground-water contamination in upstate New York has not been fully assessed. The first significant documentation of pesticide contamination in upstate New York came in 1983 when analyses by Cornell University and other researchers detected aldicarb in ground water at levels exceeding $1 \mu \mathrm{g} / \mathrm{L}$ at approximately 30 percent of 76 sites in areas considered to be at risk of aldicarb contamination (New York State Department of Environmental Conservation, 1987, p. II-13).

\section{Nitrate}

Ground-water contamination by nitrate (as nitrogen) is a less severe problem than contamination by soc because its health effects are less. Ground-water contamination by nitrate is widespread in the upper glacial aquifer on Long Island (fig. 3B) and, although not widespread in upstate New York, it presents a problem in some areas. Sources of nitrate contamination include: (1) agricultural and turf fertilizers, (2) onsite sewage-disposal systems, (3) animal wastes, and (4) landfills. When large numbers of onsite sewagedisposal systems are concentrated over an aquifer, they constitute a significant source of nitrate contamination.

The effect of urbanization on the concentrations of dissolved solids and nitrate in ground water in the upper glacial and Magothy aquifers of Nassau and Suffolk Counties, Long Island, is illustrated in figure 4. Concentrations of both water-quality constituents are greater in Nassau County, the more densely populated, and in the upper glacial aquifer, the uppermost aquifer. Median concentrations have increased with time as development has increased.

Nitrate concentrations of about $10 \mathrm{mg} / \mathrm{L}$, the primary standard for drinking-water supplies, were found in ground water under many unsewered or recently sewered areas of Nassau County. At the end of 1982 , the use of 19 public water-supply wells in Nassau County was restricted because nitrate concentrations exceeded the standard (New York State Department of Environmental Conservation, 1986 , p. II-15). The nitrate problem also affects private household wells. Since 1972, almost 19,000 ground-water samples from Suffolk County have been analyzed for nitrate, 7.7 percent of which exceeded the 10-mg/L standard (Suffolk County Department of Health Services, 1984, p. 11). Statewide, perhaps as many as 5,000 private wells are contaminated by nitrate (Association of State and Interstate Water Pollution Control Administrators, 1985).

\section{Chloride}

Chloride contamination of household wells is not uncommon, but few public water-supply wells in the State have been affected in recent years. Chloride can make water supplies unsuitable for drinking, but it is not a major public-health risk at concentrations found in most ground water. Sources of chloride include: (1) onsite domestic sewage-disposal systems, (2) storage and use of roaddeicing salts, (3) landfills, (4) saltwater intrusion on Long Island, and (5) natural salt deposits underlying western and central New York.

Chloride contamination due to excess pumpage was responsible for the closing of many public-supply wells on western Long Island from the early 1900's through 1974. The aquifer under this area is no longer excessively pumped for drinking-water supply. Several public-supply wells in Nassau and Suffolk Counties operate under pumpage restrictions because of the potential for saltwater intrusion.

\section{Other Organic Chemicals and Toxic Metals}

Ground-water contamination by organic compounds other than those discussed earlier has not been widespread. Among the other organic compounds that have been detected in public-supply wells are polychlorinated biphenyls (PCB's), chloroform, vinyl chloride, and carbon tetrachloride. Concentrations are generally less than State drinking-water standards, with few exceptions (New York Department of Environmental Conservation, 1987, p. II-15).

Toxic-metal contamination of ground water is not widespread, but significant local instances of such contamination have been documented. Plumes of toxic-metal contamination have been identified around landfills and industrial-waste disposal sites.

\section{Potential for Water-Quality Changes}

Ground-water-quality problems will continue as a consequence of past, present, and future development. In New York, the areas of most intense ground-water use generally have permeable soils that allow contaminants to move readily from the surface downward to the aquifer without significant attenuation. These areas also are characterized generally by substantial or intense urban, industrial, and agricultural development. On Long Island in particular, 
all development and, therefore, all potential sources of contamination are directly above the principal aquifers. Because the aquifers are the sole source of drinking water for about 3.2 million people, their protection is vital. The greatest concern today (1986) is directed toward Long Island's deeper aquifers, which are the major source of public water supply (New York State Department of Environmental Conservation, 1986, p. II-3). In short, where ground water is most readily available and most intensely used in New York, it also is most vulnerable to contamination.

Thousands of potential sources of contaminants, including toxic substances, currently overlie the State's important aquifers, and the number of potential sources probably will increase, even though development will be increasingly regulated. Many potential sources of contaminants that accompany development are not readily controlled; for example, railroad and truck accidents will continue to cause chemical and petroleum spills.

Petroleum products and SOC are expected to remain the cause of New York's most serious ground-water-quality problems. The storage and handling of those materials, even though regulated, create a constant potential for spills and leaks. Steel petroleumstorage tanks, for example, are being replaced by fiberglass tanks, which do not corrode, yet they are subject to leaks from accidental fracturing.

Active and inactive hazardous-waste-disposal sites will continue to be sources of toxic organic contaminants. Pesticide contamination of ground water will remain a concern. Changing agricultural practices, such as the increase in tilled acreage, may increase the potential for pesticide migration to ground water.

Nitrate contamination of Long Island's major public-supply aquifers also is expected to remain a concern. The continued increased concentrations of nitrate in aquifers underlying sewered areas indicate that uncontrolled sources of nitrate, such as lawn fertilizers, are persisting, and they will continue to be a concern (New York State Department of Environmental Conservation, 1986, p. II-A).

The major areas of ground-water contamination in New York probably have been identified; therefore, as more complete data are gathered in the future, a large number of unexpected well closings is unlikely. Yet, ground-water contamination threatens to expand if strong actions are not taken. Consequently, New York State has conducted a review of its ground-water resources and developed a thorough ground-water-management program.

\section{GROUND-WATER-QUALITY MANAGEMENT}

Two State agencies, NYSDEC and NYSDOH, have responsibility for most aspects of the State's ground-water-management program. These agencies also have been delegated responsibility for implementing many Federal programs related to ground water.

The NYSDEC, the State's environmental agency, is responsible for administering a full array of environmental-quality and natural-resource programs such as ground-water resource management, program development, and interagency coordination. Specifically, NYSDEC is charged with the "coordinated management of water resources" (Environmental Conservation Law, Section 3-0301) and the control of water pollution and maintenance of reasonable standards of purity of the State's ground and surface water (Environmental Conservation Law, Article 17).

The NYSDOH works closely with the NYSDEC in ground-water policy development and oversight. Under the New York State Public Health Law, NYSDOH is responsible for the protection of public health and for ensuring a safe supply of drinking water for the State's citizens. This responsibility pertains to water that is pumped by water suppliers for distribution to the consumer. Under the Public Health Law and Part 5 of the State Sanitary Code, NYSDOH administers a major program to ensure that all water-supply systems in the State are operated and maintained properly and that all consumers are assured delivery of a safe and adequate supply of water.
New York State's government has long recognized the value of ground-water resources. Since the 1930's, the State has had the authority and has administered programs to regulate most groundwater withdrawals on Long 1sland. During the 1950's and 1960's it provided substantial funds for county and basinwide waterresource studies for most of the State in cooperation with the U.S. Geological Survey. These efforts resulted in many ground-water maps and interpretive reports.

New York State has had a system of ground-water-quality classifications and standards since 1967. The most recent revision, in 1978, included effluent standards and limitations that provide the basis for State Pollutant Discharge Elimination Systems (SPDES) permits. New York State requires sPDES permits for all municipal, industrial, and commercial wastewater discharges to ground water.

In addition to those initiatives that specifically address ground water, the NYSDEC currently administers a range of programs in areas such as solid- and hazardous-waste disposal, pesticide use, mined-land reclamation, oil and gas regulation, and others that have helped to protect ground water in the past and are being adjusted to continue this protection in the future.

Despite the current programs to protect ground water, evidence indicates that past efforts have been inadequate to meet the task. For several years, the State has undertaken significant measures toward development of a new ground-water program, partly funded by grants from EPA under Section 208 of the Clean Water Act.

The State's overall management strategy is set forth in two major reports. The Long 1sland Groundwater Management Program report (New York State Department of Environmental Conservation, 1986) was certified to EPA in mid-1986. The Upstate New York Groundwater Management Program (New York State Department of Environmental Conservation, 1987) was certified to EPA in May 1987.

The primary emphases of New York State's ground-waterprotection strategy, as defined in these documents, are: (1) to strengthen its current programs that regulate contamination sources so ground-water problems may be better anticipated and prevented; (2) to geographically target special regulatory policies to provide a more intensive management focus on the largest yielding and most intensively utilized aquifers; (3) to develop new regulatory programs for important contamination sources that are not addressed adequately at the present time, particularly petroleum and chemical bulk storage; and (4) to work closely with local government agencies to foster protection of critical aquifers.

The State currently is implementing some of the key recommendations contained in these reports. It is (1) supporting a program with the U.S. Geological Survey to update and expand the available aquifer maps; (2) implementing policies to restrict the location of landfills over principal aquifers; (3) improving management of the SPDES program to control toxic discharges to both ground water and surface water; (4) developing regulations to implement the State's Petroleum Bulk Storage Law (passed in 1983); and (5) continuing efforts to improve water-quantity management on Long Island.

The State's ground-water-management strategy incorporates Federal programs delegated to the State under legislation, such as the Safe Drinking Water Act, CERCLA, and RCRA. In general, authorities in these acts are paralleled by State legislation, which in some instances goes beyond the Federal counterpart. For example, the State's SPDES program regulates wastewater discharges to surface water and ground water, whereas the Federal National Pollutant and Discharge Elimination System regulates only surfacewater discharges. Also, a State Superfund has been established to renovate hazardous-waste sites not under the Federal Superfund (CERCLA)

County health agencies in New York State have long assisted in conducting the State's pollution-control and water-supply- 
regulation programs through delegation and local assistance. Some counties administer additional programs of their own, especially on Long Island. Historically, local health agencies have conducted most of the day-to-day activities within the Long Island Groundwater Management Program. Suffolk County's Article 12 program is one of the best examples of a strong preventive regulatory program for petroleum and chemical bulk storage. The Long Island Groundwater Management Program (New York State Department of Environmental Conservation, 1986) is neither a purely State nor a purely local program, but rather, a comprehensive framework for the activities of several independent State and local agencies.

Towns, cities, and villages in New York State are responsible for regulating land use, a key factor in protecting ground water. Few municipalities in New York State have made full use of local zoning, subdivision approval, and other land-use control powers to protect ground water, although some local governments, particularly on Long Island, have begun to do so. An important element of the State's long-term strategy is to improve guidance to local governments to assist the development of effective local protection efforts.

\section{SELECTED REFERENCES}

Association of State and Interstate Water Pollution Control Administrators, 1985, America's clean water, the States nonpoint source assessment 1985-Appendix: Washington, D.C., Association of State and Interstate Pollution Control Administrators, 530 p.
Eckhardt, D.A., Flipse, W.J., Jr., and Oaksford, E.T., 1987, Relation between land use and ground-water quality in the upper glacial aquifer in Nassau and Suffolk Counties on Long Island, New York: U.S. Geological Survey Water-Resources Investigations Report 86-4142. [in press.]

New York State Department of Environmental Conservation, 1985, Inactive hazardous waste disposal sites in New York State-Annual report: Albany, Division of Solid and Hazardous Waste.

1986, Final Long Island ground-water management program: Albany, Division of Water.

1987, Final Upstate New York groundwater management program: Albany, Division of water.

Suffolk County Department of Health Services, 1984, Report on water supply priorities: Suffolk County, New York, Department of Health Services, Drinking Water Section, Bureau of Water Resources, 19 p.

U.S. Department of Defense, 1986, Status of the Department of Defense Installation Restoration Program-Information paper: Washington, D.C., U.S. Department of Defense, Office of the Assistant Secretary of Defense (Acquisition and Logistics), Environmental Policy Directorate, February, $35 \mathrm{p}$

U.S. Environmental Protection Agency, 1986a, Maximum contaminant levels (subpart B of part 141, National interim primary drinking-water regulations): U.S. Code of Federal Regulations, Title 40, Parts 100 to 149 , revised as of July 1,1986 , p. 524-528.

$1986 \mathrm{~b}$, Secondary maximum contaminant levels (section 143.3 of part 143, National secondary drinking-water regulations): U.S. Code of Federal Regulations, Title 40, Parts 100 to 149 , revised as of July 1,1986 , p. $587-590$.

1986c, Amendment to National Oil and Hazardous Substances Contingency Plan; national priorities list, final rule and proposed rule: Federal Register, v. 51, no. 111, June 10, 1986, p. 21053-21112.

U.S. Geological Survey, 1985, National water summary 1984-Hydrologic events, selected water-quality trends, and ground-water resources: U.S. Geological Survey Water-Supply Paper 2275, $467 \mathrm{p}$.

Prepared by R.J. Rogers, U.S. Geological Survey, and staff of Division of Water, New York State Department of Environmental Conservation.

FOR ADDITIONAL INFORMATION: District Chief, U.S. Geological Survey, P.O. Box 1669, Albany, N.Y. 12201 


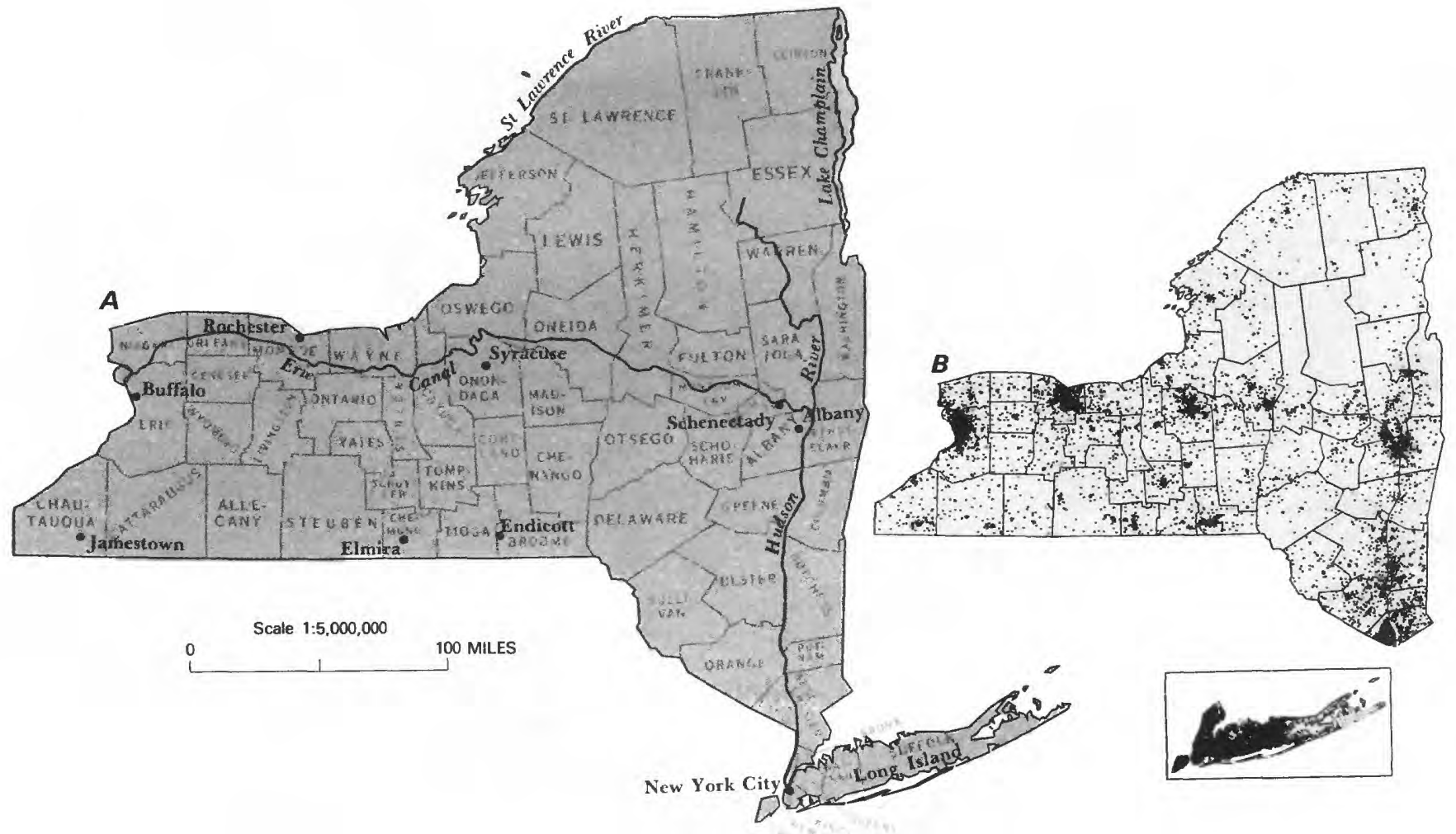

Figure 1. Selected geographic features and 1985 population distribution in New York. A, Counties, selected cities, and major drainages. B, Population distribution, 1985; each dot on the map represents 1.000 people. ISource: B. Data from U.S. Bureau of the Census 1980 decennial census files, adjusted to the 1985 U.S. Bureau of the Census data for county populations. I 
PRINCIPAL AQUIFER - Numeral is

aquifer number in figure $2 \mathrm{C}$

STRATIFIED-DRIFT DEPOSITS

Lacustrine and ice-contact deposits (1)

Valley-fill (1-5)

Upper glacial $(6,7)$

Nassau County (6)

Suffolk County (7)

UNCONSOLIDATED COASTAL PLAIN AQUIFERS

Magothy (8,9)

Nassau County (8)

Suffolk County (9)

Lloyd (10)

BEDROCK AQUIFERS

Carbonate (11)

Sandstone (12)

Not a principal aquifer

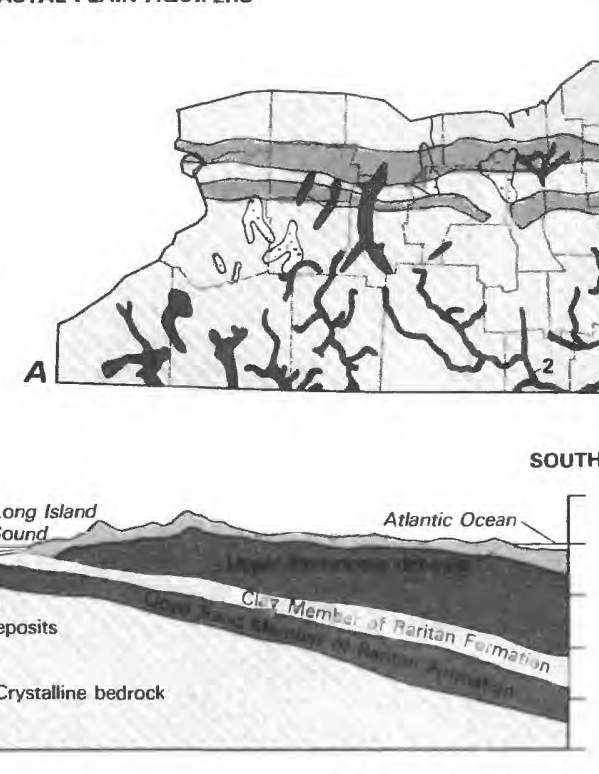

C

\section{WATER-QUALITY DATA}

Percentile - Percentage of analyses equal

to or less than indicated values

90th

$1-75$ th

4 - 50 th

-25th

National drinking-water standards

Maximum permissible contaminant level (primary)

- - Maximum recommended contaminant level (secondary)

Reporting limit

Minimum reporting level with analytical method used
NUMBER OF ANALYSES

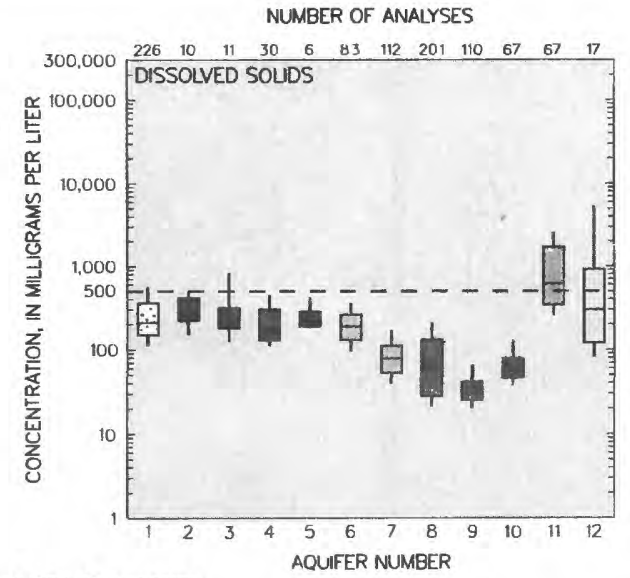

NUMBER OF ANALYSES

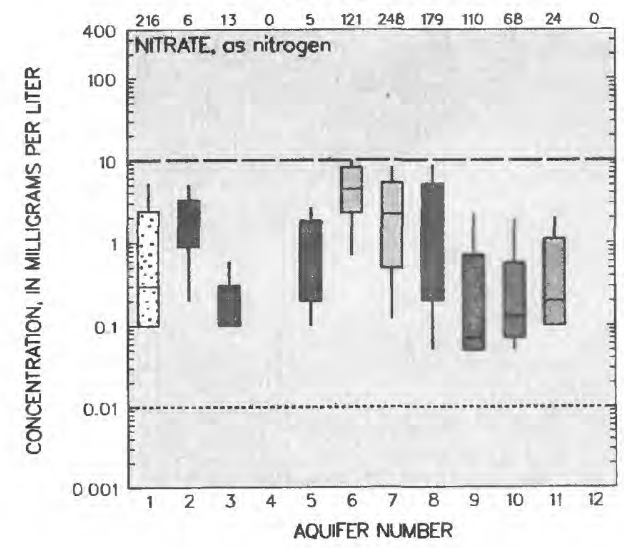

NUMBER OF ANALYSES

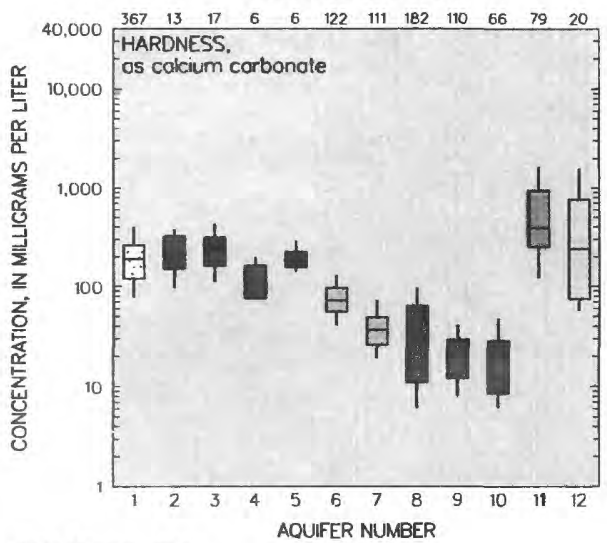

NUMBER OF ANALYSES

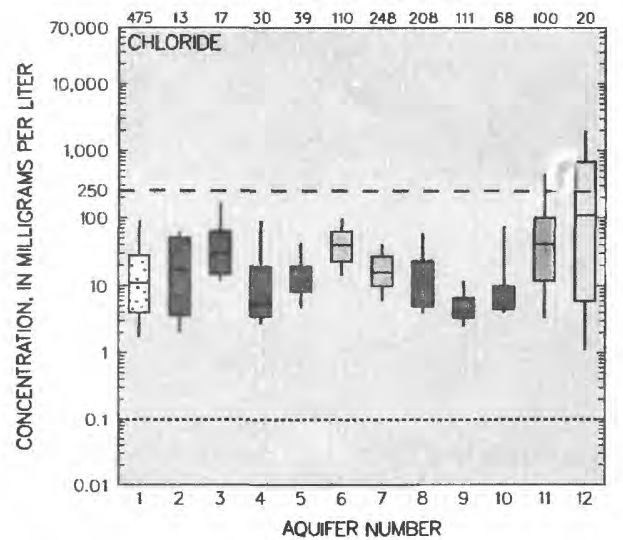

Figure 2. Principal aquifers and related water-quality data in New York. A, Principal aquifers. $B$, Generalized hydrogeologic section. $C$, Selected waterquality constituents and properties, as of 1985. ISources: $A$ and B. U.S. Geological Survey, 1985, fig. 1. C, Analyses compiled from U.S. Geological Survey files; national drinking-water standards from U.S. Environmental Protection Agency, 1986a,b). 


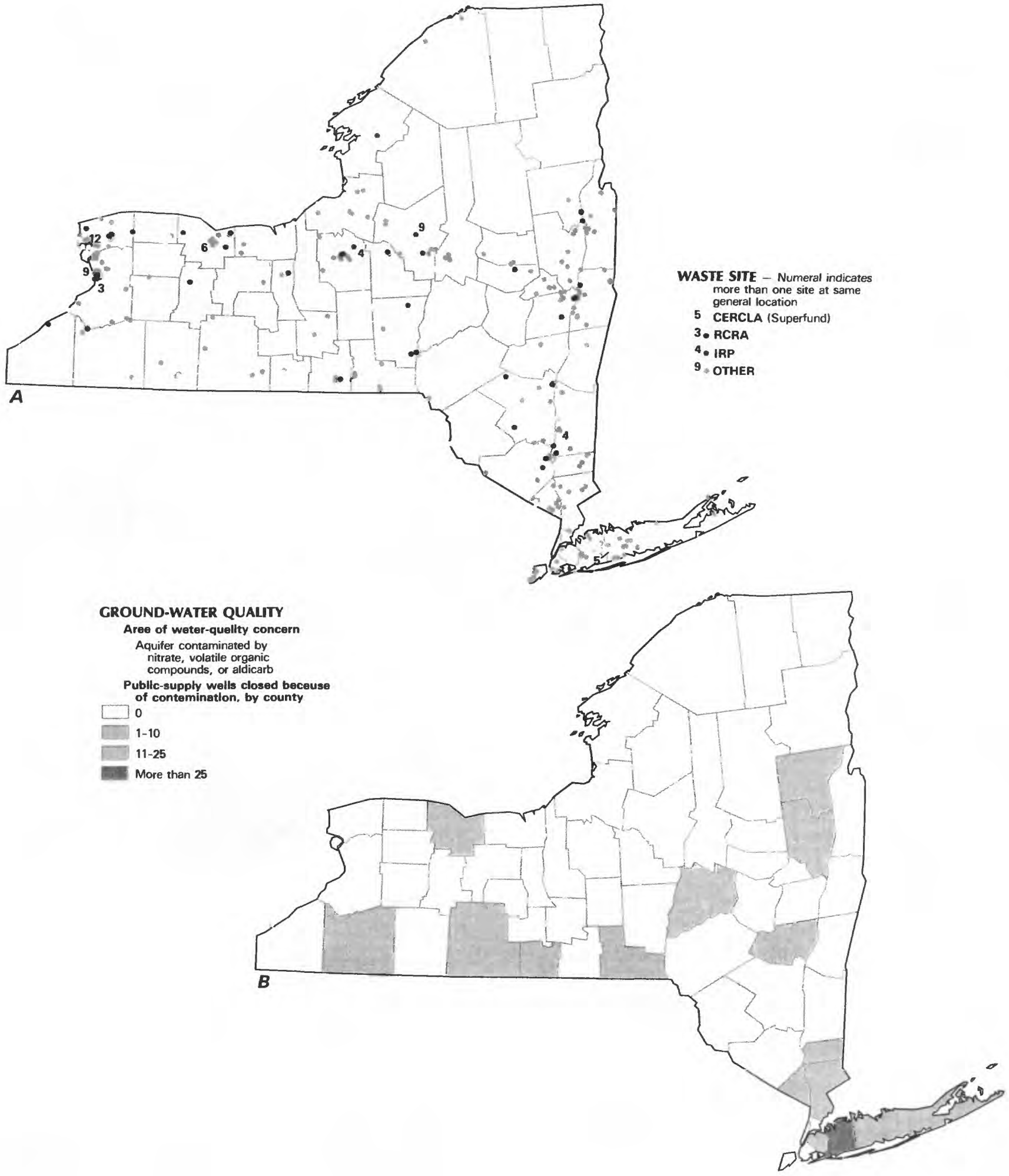

Figure 3. Selected waste sites and ground-water-quality information in New York. A, Comprehensive Environmental Response, Compensation, and Liability Act (CERCLA) sites, as of 1986; Resources Conservation and Recovery Act (RCRA) sites, as of 1986; Department of Defense Installation Restoration Program (IRP) sites, as of 1986; and other selected waste sites, as of 1986. B. Areas of human-induced contamination, and distribution of public-supply wells closed because of contamination, as of 1986. C. County and municipal landfills, as of 1986. (Sources: A, U.S. Environmental Protection Agency, 1986c; Michell Taylor and Edward Miles, New York State Department of Environmental Conservation, oral commun., 1986; U.S. Department of Defense, 1986; New York State Department of Environmental Conservation, 1985b. B. New York State Department of Environmental Conservation, 1986; R. A. Entringer, New York State Department of Health, written commun., 1986. C, J. A. Sacco, New York State Department of Environmental Conservation, written commun., 1986.I 


\section{LANDFILI SITE}

County or municipal landfills.

by county - Active and inactive

$\begin{array}{ll}\square & 0 \\ \square & 1-3 \\ \square & 4-10 \\ \square & 11-20 \\ & 21-50\end{array}$

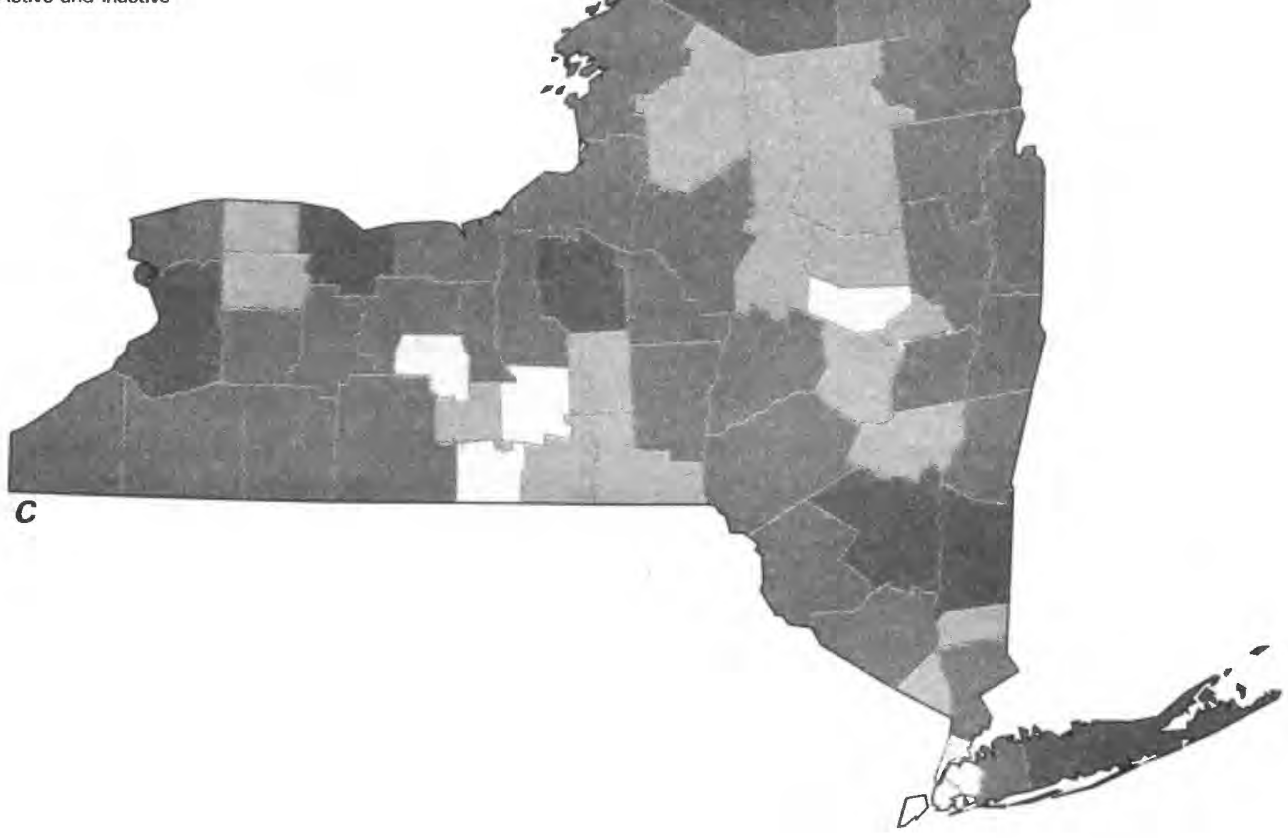

Figure 3.-Continued. 

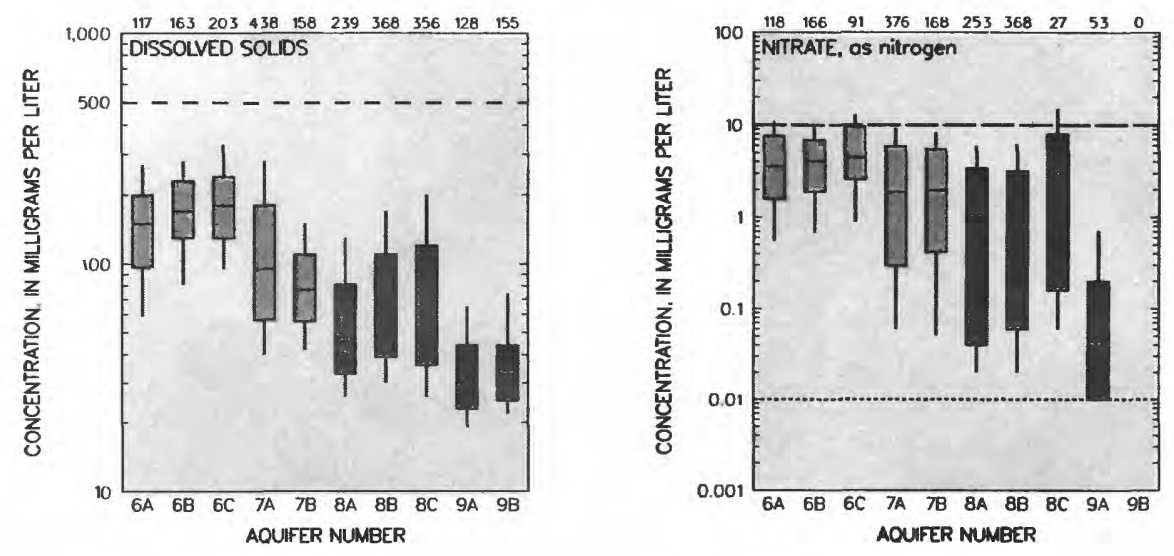
Aquifer identification
Upper glacial aquifer, Nassau Co.
6A. 1960-64
6B, $1970-74$
6C, $1980-84$
Upper glacial aquifer, Suffolk Co.
7A, 1970-74
$7 B, 1980-84$
Magothy aquifer, Nassau Co.
8A. 1960-64
8B, 1970-74
8C, 1980-84
Magothy aquifer, Suffolk Co.
9A, 1970-74
9B, $1980-84$

WATER-QUALITY DATA

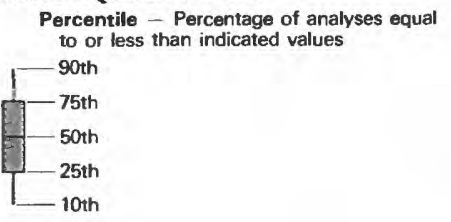

National drinking-water stendards

Maximum permissible contaminant level (primary)

- - - Maximum recommended contaminant

level (secondary)

Reporting IImit

Minimum reporting level with

analytic method used

Figure 4. Dissolved-solids and nitrate in the upper glacial and Magothy aquifers of Nassau and Suffolk Counties, Long Island, 1960-84. Aquifer locations as given in fig. 2. (Source: U.S. Geological Survey files.) 